UDC 82-31

DOI https://doi.org/10.32782/tps2663-4880/2020.14-2.41

\title{
CRITICAL ATTITUDE THE TENDENCY OF ADVENTURE AND MODERNIZATION IN HISTORICAL PROSE
}

\author{
КРИТИЧНЕ СТАВЛЕННЯ ДО ТЕНДЕНЦЇ АВАНТЮРНОСТІ ТА МОДЕРНІЗАЦЇ̈ \\ В ІСТОРИЧНІЙ ПРОЗІ
}

\author{
Najafova Bika, \\ orcid.org/0000-0002-8033-542X \\ PhD Student \\ Azerbaijan Teachers' Institute
}

\begin{abstract}
Approaches to adventurous and modernization trends in the 1960-1980 edition of literary criticism. Breaking the boundaries of adventure, modernization, and modernization with the use of adventure elements in artistic creativity has always been a challenge to literary criticism. The article highlights the attitude of the literary critique of this issue in the artistic development of the historical truth in the 1960-1980s. Despite the possible use of adventure elements in literary criticism, it focuses on the conclusion that accurately defines the image of historical events in an adventurous direction. The focus of the literary criticism on the refinement of the story is that it is transformed and summarized as an object of analysis into the fact that this aspect of damage to the objective development of history is damaged. It should be said that historicity has become a necessary aesthetic requirement for the genre after the emergence of more social novels. Whether the knighthood or the adventure novels have become the main function of entertaining the reader, the relevance of the literary content to the actual or historical reality has not become an aesthetic requirement. However, it is noteworthy that even though social novels have undergone a serious evolutionary process compared to novels of knighthood and adventure, and have acquired their true genre quality in the $19^{\text {th }}$ century, there are some or other traits inherent in its nature. It is true that even in the modern historical novel, the elements of the adventure remain. Despite the fact that criticism and literary criticism are often critical of the adventurous descriptions in the novel, it should be noted that this quality comes from the historical tradition of the novel. Adventurous, adventure elements in Soviet literary and criticism have often been considered an artistic flaw for historical novels. Literary criticism has generally seen an increasing tendency to adventure in the artistic expression of historicity, leading to a more rigid and demanding approach to the issue.
\end{abstract}

Key words: adventure, modernity, modernization, historical truth, artistic truth, artistic development.

Підходи до авантюрних і модернізаційних тенденцій у виданні літературознавства 1960-1980 років. Порушення меж пригод, модернізації та модернізації із застосуванням пригодних елементів у художній творчості завжди було викликом літературознавству. У статті висвітлено ставлення літературної критики цього питання до художнього розвитку історичної правди у 1960-1980-х роках. Незважаючи на можливе використання авантюрних елементів у літературознавстві, він зосереджується на висновку, який точно визначає образ історичних подій у авантюрному напрямі. Основна увага літературознавства на вишуканості розповіді полягає в тому, що вона перетворюється та узагальнюється як об’єкт аналізу в той фракт, що цей аспект пошкоджує об'єктивний розвиток історії. Слід сказати, що історичність стала необхідною естетичною вимогою до жанру після появи більш соціальних романів. Незалежно від того, чи стали лицарські чи пригодницькі романи основною функцією розваги читача, відповідність літературного змісту реальній чи історичній дійсності не стала естетичною вимогою. Однак, прикметно, що, хоча соціальні романи пройшли серйозний еволюційний процес порівняно з романами лицарства та пригодницьких дій і набули своєї справжньої жанрової якості у XIX столітті, є ті чи інші риси, притаманні їхній природі. Це правда, що навіть у сучасному історичному романі елементи пригоди залишаються. Незважаючи на те, що критика та літературознавство часто критично ставляться до авантюрних описів у романі, слід зазначити, що ця якість походить від історичної традиції роману. Пригодницькі елементи в радянській літературі та критиці часто вважалися мистецькою вадою історичних романів. в літературознавстві загалом спостерігається зростальна тенденція до пригод у художньому вираженні історичності, що приводить до більш жорсткого і вимогливого підходу до цього питання.

Ключові слова: пригода, сучасність, модернізація, історична правда, художня правда, мистецький розвиток.

Introduction. The novel, as a genre, had a strong evolutionary process in the $20^{\text {th }}$ century, and more and more manifested in the philosophical nature of its social context. These tendencies in the genre's evolution of the novel also apply to the historical novel. We have already mentioned that two types of aesthetics based on this type of novel. However, it should be said that historicity has become a necessary aesthetic requirement for the genre after the emergence of more social novels. Whether the knighthood or the adventure novels have become the main function of entertaining the reader, the relevance of the literary content to the actual or historical reality has not become an aesthetic requirement. However, it is noteworthy that even though social novels have undergone a serious evolutionary process compared to novels of knighthood and adventure, and have acquired their true genre quality in the $19^{\text {th }}$ century, there are some or other traits inherent in its nature. It is true that even in the modern historical novel, the elements of the adventure remain. Despite the fact that criticism and literary criticism are often criti- 
cal of the adventurous descriptions in the novel, it should be noted that this quality comes from the historical tradition of the novel. Adventurous, adventure elements in Soviet literary and criticism have often been considered an artistic flaw for historical novels. Nevertheless, in criticism and history of literature, this view is not understood clearly, and some authors even try to prove that this is a necessary quality for the novel. In this sense, the author of the well-known novel "Data Tutashkhia" Ch. Amirechibi's view in the place of adventure elements in the historical novel is of interest. Interviewed by a well-known Georgian writer on "Artisan and History" H. Mitin posits that your novel "The Adventures of Mursi or Shipov" by B. Okudjawa, V. Bogomolov's "In August 1944", etc. He has a "literary relationship" with his works. The author of the interview, who points out that these and other facts are "an indication of the particular tendency of serious writers to adventure", asks the writer why. The writer's answer is quite logical: "No matter how serious the novel may be, it can carry adventure elements. There is not any wrong with it" [11, p. 163]. The writer justifies his position as follows: This is practical cause. We live in a time when writers are experiencing a shortage of time when a potential reader is overloaded: besides the work and family care, also television, tape recordings, performances do not allow man to open his eyes. A publisher faces a daunting challenge: how could a potential reader turn off a TV or tape recorder and read a thick book! There is a way; the book we are writing should be more interesting than the entertainment the reader finds. If the book elevates and enriches spiritually the man, I assure you victory will always be with the artistic prose" [11, p. 163].

Discussion: In the thoughts of the Georgian writer, the place where the adventure, devoted to the elements of adventure, seems to us to be distinguished from adventure and occurrence. The fact that the writer places emphasis on adventure elements, not adventure, and adventure elements, rather than adventure in the historic prose is a fairly correct position from a scientific point of view.

Even in literary criticism we encounter cases of "popularity", in other words, justifying the tendency of replacing the historically with adventure for gaining the mass reader. Prof. B. Ahmedov writes, “... There is an interesting adventure and ease in the style of A. Jafarzadeh, which in fact has made this writer's novels very popular $<\ldots>$ As the main character of A. Jafarzade's novels, adventure, ease, readability, the writer here has remained true to his style and managed to revive historical events and personalities in a new era. In fact, adventure is one of the main com- ponents of not only A. Jafarzadeh's historical novels, but also of historical novels in general. Critics have also mentioned being adventure in the novel of M.S. Ordubadi "Sword and Quill" at one time. On the other hand, it can be said that he appealed to the adventurous style of A. Jafarzadeh to address the readers' problem for the first time, in order to increase interest in the historical novel and gain a wide readership" [2, p. 472-473]. There is enough room for polemics in these considerations. The researcher errs in favor of adventure style for a historical novel. Because of adventure is not a complementary feature of history, but a quality that undermines it and distorts historical reality.

Secondly, the researcher makes a mistake when evaluating "popularity" as a key criterion for evaluating a historical novel. Because popularity is a feature that is tailored the pleasure of the reader and it cannot serve as a defining feature of the work's aesthetic appeal. The emerging intensity of the adventurous tendency in historical novels dating back to the 1960s and 1980s prompted the study of literary criticism to give him an analytical scientific attitude and the difference between history and adventure. Literary criticism relates to the notion of "incompatibility of the elements of adventure with a strict historical novel style" [6, p. 167], trying to discern the difference between "exotic interest" with a personal approach to each literary sample. Critic V. Guliyev in the work of F. Karimzadeh "The Bridge of Khoodafarin" "The part of Shah Ismail's life undergoing constant displacement and persecution gave the author of the novel ample opportunities for adventure V. Guliyev considers Kerimzade's rejection of this opportunity as a correct way of artistic expression of history" [6, p. 167].

However, literary criticism has generally seen an increasing tendency to adventure in the artistic expression of historicity, leading to a more rigid and demanding approach to the issue. The critic N. Jabbarov expressed his scientific view of the problem as follows: "To be honest, the tendency to appeal to historical events with an exotic interest to our greatest historical personalities, at worst, is still going on. For example, three novels about Shah Ismail Khatai have appeared recently. However, these three novels are not able to give the modern reader the desirable information about this great representative of our national existence" [9, p. 182]. It is good that the literary criticism is not limited to general considerations when looking at the issue, revealing the different manifestations of the problem by bringing individual novels to the forefront of personal analysis. For example, criticism quite 
rightly distinguishes "Khodaafarin Bridges" in terms of the manifestation of history as an artistic concept, in novels such as "Swinging Sword", "Baku - 1501", "Life that became a song", "Khagani", as well as in the narratives of Madame Gadri (Gilman Ilkin) and "Jalaliyya" (A. Jafarzadeh) tried to determine the moments in which historicity has surrendered to adventure. The important thing was that, this aspect of art has lost its sense of art, drawing attention to the negative role played by the artistic expression of historical facts. Critic A. Huseynov points out that the tendency to adventure in the "Madam Gadri" narrative has been overshadowed by the fact that historical facts have been overshadowed and hindered by the creation of an objective picture of the era. "The main disadvantage of narrative is that the social-class conflict is covered in a detective plot. This is true, revolutionary fighting conditions, secret and openended examples of openness give many opportunities to dramatize events, increase the tension of events, but adventurous attempts should not shade the realist image and psychological analysis into life [3, p. 230]. The critic defines the main task facing the historical prose in the context of the "Madam Gadri" narrative as follows: "Historical thinking means a periodic influence, reviving time and people with new and essential features and vitality" [3, p. 175]. According to the critic, no matter how much or how analytical artistic prestige, realism or history is defined by the concept of literary writer, one cannot expect that these works will add to the tradition, reflect innovations, or frustrate the reader. While attempting to summarize the basic typological tendencies of the $60 \mathrm{~s}$ and $80 \mathrm{~s}$, historical criticism, S. Salmanov emphasizes; "above all, certain schemes and habits stabilized in the development of historical themes". This observation is accurate. The overlapping schemes in the historical prose have been linked to the inability of the artistic mind to absorb the historical material and to "digest the history with its own writer's imagination". When historical material comes to a work of art such as a finished plot and image, and the author's own unique view, the historical material is transferred from one writer's work to another, thus "stabilizing schemes and habits". "We should consider that a true literary work which written in a historical genre above all, should be a serious artistic exploration of the historical past" [10, p. 176].

Although, as we have already seen, criticism and literary criticism is generally opposed to adventurous portrayal of historical novels with adventurous descriptions, although they attempt to justify the author's personal style of adventure in the historical prose and pave the way for his readership, show particular sensitivity to this aspect of the issue. In this sense, the views of critics A. Huseynov and V. Guliyev on A. Jafarzadeh's novel "Baku-1501" are objective.

The critic V. Guliyev concludes that A. Jafarzadeh in the "Shirvan" trilogy and in "Baku-1501" ignores the true historical facts; builds the plot and character of the characters based on their romantic thinking and understanding. According to the critic, there is an indifference to the historical character of the image in A. Jafarzade's style, or it is difficult to see, understand and evaluate the historical character of the author's image; significant aspects of the life and activities of Nijat Shirvani, Seyed Azim, Abbas Sahhat, as well as Shah Ismail's history and work are not included in the novels. The critic writes: "But for some reason, every time such moments go to the background in A. Jafarzadeh's commentary, adventures of love, romantic feelings about historical heroes and so on. covers them"(7). What is the reason for this, and what are the consequences of this tendency in history? This is one of the most important problems to think critically. The critical issue dealt seriously: How does the Georgian prose create a fugitive image such as Data Tutashkhia? After all, the Georgian people have no such hero. So, based on what aesthetic legitimacy the Georgian writer $\mathrm{Ch}$. Amirecibi can turn Data Tutashkhia into a hero that carries the most remarkable features of the Georgian history? In our case, the rich history of the Fugitive Karam, which became legendary in the late $19^{\text {th }}$ and early $20^{\text {th }}$ centuries, does not maintain its historical grandeur. Critics cannot stay they cannot stay when speak about F. Eyvazli's novel, "Fugitive Karam" or the narrative of "Karam Square" without compare it with the "Data Tutashchia" novel. A. Mammadov writes: Let us recall Ch. Amirecibi's work "Data Tutashchia" and F. Eyvazli's novel "Fugitive Karam". The fictional literary hero Data Tutashkhia has become the embodiment of the best features of the Georgian character - courage, aggression, humor and sense of justice - as if readers were imagining a real human status. Farman Eyvazli has written a novel about Fugitive Karam who is a real hero, and people created epos about him. The novel was very pale, and its hero can only be called a hero in literary criticism" [8, p. 112].

The critic sees the reason for these failures in writers' national history novels as "the literary tale of what is known from historical sources" [8, p. 113]. A. Mammadov tries to prove by quoting from Y. Garayev that "household, ethnographic details, misrepresentations from the chronicles, and even the inclination to the level of the medieval historian, overshadow the image of historical figures" [8, p. 113]. 
In general, the tendency to adventure in the $60-80 \mathrm{~s}$ of the 1980s is to reflect on the serious differences between a literary critical social novel and an adventure novel, and the place where social elements play in the novel. He encouraged the formation of a scientific and theoretical conception of the world, which necessitated explaining the ways in which this problem could be solved in world literature. The critic P. Khalilov explains the difference between a social novel and an adventure novel as follows: “... In social novels, along with human psychology, is paid attention to the analysis of social factors and the social process. Adventure novels are also at the center of man, his mental state and excitement may not be the object of his description here. But in this genre, the dynamics of the event, the frequency and frequency of its occurrence, are more characteristic, so you do not need to stand on the details of the event" [4, p. 76]. In essence, this means that as the story unfolds in the adventure novel, the ability to penetrate one's soul and psychology becomes weak. It is welcomed naturally for the genre to express itself. But when the author, in a social or historical novel, follows this path - the story behind the story goes into the background of the psychological influence of the human nature, the study of socio-historical processes. Therefore, the genre is removed from its nature. The historical novel, the author without even realizing it, becomes an adventure novel. The criticism focuses on the history of adventure in the world literature in the novel: "In the works of A. Pushkin, M. Lermontov, L. Tolstoy, F. Dostoevsky, I. Turgenev, I. Goncharov, the national lifestyle of the Russian society is reflected in epic expansions, in many colorful pictures, as well as in the council of pleasure of the subcultures, in the scores... In the work of "War and Peace" we find countless dance scenes" $[4$, p. 77]. That is, it is possible in the historical novel to describe the events of adventure and even their detailed description. But under what conditions? The condition is that the inclusion of such events in the plot should result from the requirements of artistic logic and carry a specific aesthetic function. If after the event the image of the event does not become an organic part of the author's aesthetic attitude to the history, does not serve to reflect in the historical context and coloring, and the image itself is not the means to achieve the goal, then the adventure begins. This is exactly what criticism is all about. In the works of "War and Peace", as well as in the works of the above-mentioned Russian writers, P. Khalilov has the right to regard the allocation of space for the depiction of archetypes as an expression of historical calorie rather than adventure. Therefore, here detail is a tool that helps both coloring of description and appealing standpoint of a writer. These observations and conclusions of criticism ultimately lead to the fact that the national work must perfectly absorb the historical traditions of world literature, and absorb the socio-philosophical content of the historical period, which has become the object of literary analysis. The criticism comes from the fact that A. Jafarzadeh's novel "Baku-1501" lacks such a feature and, as a result, his inability to approach the subject with the logic of history, while the advent of adventure is inevitable. V. Guliyev proves that adventures in the novel "Baku-1501" are superior to the description of historical facts. He writes: "The work covers 14 years (1501-1514) of Shah Ismail's life full of struggles and triumphs. The author also returns to the childhood years of the young ruler when he comes to the place, and also publishes various dramatic pages of his 15 -year life until his throne. However, the history of the transmitted life is often revived based on imagination flights, not based on historical memory. This sometimes does not coincide with the style of a serious historical novel, and it challenges the adventurous tendencies. The adventure novel starting with the chapter "A Day in the Basket", deepens in the Aytakin-Ibrahim line and undermines the historicity of the work" [1, p. 27-28].

Conclusion. A comprehensive analysis of the critic A. Huseynov's novel "Baku-1501" is the most notable example of this concern. Critics who observe that the style of the novel has become more and more adventurous, the trend remains to be seen, especially in the fate of Aitekin. The author's historical narrative, the finding of the type of conflict that provides the basis for serious historical novels, and the narrative of the author's departure from the narrative of the story, at the critical juncture of the conclusion that history can be loaded with intense dramatism on its own logic. The critic believes that the historical reality and the historical expression of the history point to this aspect of the plot development, but the course of events in the novel continues in a different way.

\section{REFERENCES:}

1. Literary process. 81-82. Baku : Science, 1987. $302 \mathrm{p}$.

2. Ahmadov B. The Azerbaijani literature of the XX century. Baku : Science and Education, 2015. $552 \mathrm{p}$.

3. Huseynov A. The criterion of art. Baku : Printer, 1986. 315 p.

4. Khalilov D. Horizons of our prose. Baku : Writer 1982, 183 p.

5. Selected works by F. Kocharli. 
6. Guliyev V. Our prose and history. Azerbaijan Magazine. 1984. No. 4. P. 164-175.

7. Guliyev V. History demands seriousness. The "Literature and Art" newspaper. April 25, 1986.

8. Mammadov A. Until our words are heard. Baku : Printer, 1988. 248 p.

9. Nabiyev B. Selected works. In 5 volumes. Vol. V. Baku : Chinar-Print, 2009. 612 p.

10. Rahimov A. Our dream, our critique. Azerbaijan Magazine. 1981. No. 2. P. 137-145.

11. Salmanov S. Criticism (Literary Review of 1977). Literary Process-77. Baku : Science, 1978. P. 120-139.

УДК 821.111-31Д. Л. 09

DOI https://doi.org/10.32782/tps2663-4880/2020.14-2.42

МІФОСВІТ РОМАНУ ДОРІС ЛЕССІНГ «УЩЕЛИНА»

D. LESSING`S MYTHOLOGICAL WORLD IN THE NOVEL «CLEFT»

\author{
Проскуріна Н.Ю. \\ orcid.org/0000-0002-9265-6618 \\ аспірант кафедри історії зарубіжної літератури і класичної філологї \\ Харківського національного університету імені В.Н. Каразіна
}

Стаття присвячена вивченню роману британської письменниці Д. Лессінг «Ущелина» (2007). Пізня творчість авторки, що традиційно розглядається у фокусі ґендерних досліджень, виявляється символічно насиченою й перспективною для вивчення в контексті неоміфологізму. Наукова розвідка має на меті аналіз художнього світу роману «Ущелина», вивчення міфосимволіки, що функціонує в тексті.

Одним із центральних фокусів статті $€$ аналіз жіночого і чоловічого світів роману. Висунуто гіпотезу, що жіноче «актуалізується» через чоловіче й навпаки. Досліджено функціонування міфосимволіки з погляду «фемінності» та «маскулінності», що виявляється в уживанні бінарних пар «лунарне-солярне», «морське-земне» тощо. Зроблено висновок, що лунарна міфосимволіка тісно пов'язана із жіночим началом, таїнством, чаклунством. Зазначено, що традиційно фемінною є водна стихія, що постає одним із першоелементів Всесвіту. У міфологічній традиції вона дуалістична: є, з одного боку, життєдайною силою, а з іншого - уособленням зла, смерті, потойбічного світу. Маскулінне начало корелює із солярною міфосимволікою.

Аналіз символіки імен довів, що номінація в романі відіграє важливу роль, трансформуючись із колективного спільного найменування в індивідуацію кожного члена суспільства. Виявлено, що символіка імен також виявляє двоїсту природу. Жіночі імена тісно пов'язані з нічним світилом, а чоловічі імена беруть свій початок від денного.

Роман Д. Лессінг «Ущелина» проаналізовано також із погляду наративних студій. Текст роману виявляє наявність декількох фокусів фокалізації. Транзит, історик епохи Нерона, «розгортає» основну історію поселення Ущелини та постає таким персонажем, що формально відсутній в оповіді, однак $є$ всезнаючим оповідачем, який говорить набагато більше за інших персонажів. Тип оповідача відповідає всезнаючому наратору, для якого притаманна оглядовість і безапеляційність, авторське вторгнення в розповідь.

Ключові слова: ґендер, міфосвіт, міфосимволіка, неоміфілогізм, фемінність.

The article is devoted to the study of the novel by British writer D. Lessing "Cleft" (2007). The late creativity of the author, traditionally viewed through the focus of gender studies, is symbolically saturated. The mentioned text proves to be challenging and suitable for study in the context of neomythologism. The paper makes an attempt to analyze the artistic world of the novel "Cleft", examine the mythological symbolism. One of the central focuses of the article is the analysis of the female and male worlds of the novel. The hypothesis is made that the feminine is "actualized" through the masculine and vice versa. The functioning of "feminine and masculine" mythosymbolics, which is revealed in the use of binary pairs "lunar-solar", "thalassian-terrestrial", etc., has been investigated. It is concluded that lunar mythosymbolism is closely related to feminine, sacrament, witchcraft. It is stated that traditionally the water element is considered to be feminine. Water is believed to be one of the first elements and in the mythological tradition is sacred, at the same time it represents both the life-giving beginning and the embodiment of evil, death, the otherworld. On the other hand, masculine correlates with solar mythosymbolism. An analysis of the symbolism of the names is presented and it is concluded that nomination in the novel plays a significant role, transforming from a collective common name to the individuality of each member of society. It is revealed that the symbolism of names has a dual nature. Female names are closely related to a night light, male names originate from daylight. An attempt is made to analyze the novel from the standpoint of narrative studies. The text of the novel reveals several focuses of the narration. Transit, a Nero-era historian, "unfolds" the main story of Cleft and appeals as a character not formally presented in the narrative, but is an all-knowing narrator who speaks much more than other characters. The type of narrator corresponds to an all-knowing editor, who is characterized by categoricalness, and authorial intrusion into the story.

Key words: Gender, mythology, mythosymbolism, neomythologism, femininity. 